\title{
Upaya Meningkatkan Sikap Positif Siswa Melalui Konseling Individu Dengan Teknik Realitas di Kelas V SDN 075046 Lolofitu
}

\author{
Rafael Lisinus Ginting \\ Radman Gulo \\ Jurusan PPB/BK FIP Unimed \\ SD Negeri 075046 Lolofitu
}

\begin{abstract}
Abstrak
Guru sering dihadapkan dengan sejumlah karakterisktik siswa yang masing-masing berbeda satu dengan yang lain. Perbedaan karakteristik tersebut berpengaruh pada sikap positif dan negatif siswa. Hal ini kemudian berpengaruh pada proses belajar mengajar sehari-hari. Sikap negatif sebaiknya dikurang dan dihilangkan, dan sikap positif harus ditingkatkan. Meningkatkan sikap positif siswa dilakukan dengan menerapkan konseling individual dengan teknik realitas.

Sikap siswa dimaksud meliputit sikap jujur, tanggung jawab, peduli, santun, dan percaya diri. Sikap adalah penilaian seseorang terhadap suatu objek, situasi, konsep, orang lain maupun dirinya sendiri akibat hasil dari proses belajar maupun pengalaman di lapangan yang menyatakan rasa suka (respon positif) dan rasa tidak suka (respon negatif). Koseling individu dengan teknik realitas adalah layanan bimbingan yang memungkinkan peserta didik mendapatkan layanan langsung tatap muka (secara perorangan) dengan guru pembimbing dalam rangka pembahasan dan pengentasan permasalahan pribadi yang dialaminya. Subjek utama penelitian ini adalah 21 orang siswa SD Negeri 075046 Lolofitu Tahun Pembelajaran 2014/2015. Teknik pengumpulan data yang digunakan adalah teknik quesioner yakni angket tertutup. Untuk menganalisis data digunakan teknik pengolahan angket Skala Likert. Temuan penelitian mengungkap bahwa sebelum diberi layanan bimbingan personal, sikap siswa tergolong negatif, sedangkan setelah diberi layanan konseling, sikap siswa menjadi positif. Total rata-rata skor sikap siswa secara keseluruhan pada prasiklus adalah sebesar 53,8 atau 44,8 \% dari skor maksimal 120 artinya sikap siswa kurang baik. Sedangkan setelah diberi layanan bimbingan personal, skor sikap siswa secara keseluruhan pada siklus I naik menjadi 77,6 atau $64,7 \%$ dari skor maksimal 120 artinya sikap siswa cukup tetapi belum mencapai batas ideal yang disyaratkan, dan total skor sikap siswa pada siklus II naik menjadi 95,4 atau 79,5\% artinya mencapai standar ideal yang disyaratkan dalam penelitian ini dengan predikat sikap siswa adalah baik. Dari hasil penelitian ini dapat disimpulkan bahwa konseling individu dengan teknik reaalitas dapat meningkatkan sikap positif siswa. Oleh karena itu disarankan kepada guru-guru SD Negeri 075046 Lolofitu agar melaksanakan layanan konseling individu dengan teknik realitas untuk meningkatkan sikap positif siswa.
\end{abstract}

Kata kunci : Sikap positif; Konseling Individual, Teknik Realitas

\section{PENDAHULUAN}

Sekolah sebagai salah satu lembaga yang menyelenggarakan pendidikan formal mempunyai peranan yang amat penting dalam usaha mendewasakan anak dan menjadikannya sebagai anggota masyarakat yang berguna.

Dalam Undang-undang RI Nomor 14 tahun 2005 tentang Guru dan Dosen BAB I pasal 1 berbunyi: guru adalah pendidik profesional dengan tugas utama mendidik, mengajar, membimbing, mengarahkan, melatih, menilai, dan mengevaluasi peserta didik pada pendidikan anak usia dini di jalur pendidikan formal, pendidikan dasar, dan pendidikan menengah. Tugas guru adalah menumbuh kembangkan dan meningkatkan modalitas sikap siswa ke arah yang lebih baik.

Pada kenyataannya guru dihadapkan dengan sejumlah karakterisktik dan sikap siswa yang beraneka ragam. Hal ini ditunjukkan oleh adanya hambatanhambatan tertentu untuk mencapai hasil 
belajar yang dapat bersifat psikologis, sosiologis, maupun fisiologis sehingga pada akhirnya dapat menyebabkan prestasi belajar secara umum berada di bawah semestinya. Perlu dipahami bahwa masing-masing individu memiliki karakter dan sikap yang berbeda-beda, ada yang memiliki sikap yang baik, ada yang sedang, dan ada pula yang kurang baik.

Dari hasil studi pendahuluan yang telah dilakukan di SDN No. 075046 Lolofitu, diketahui bahwa terdapat siswa yang cenderung menampakkan sikap yang kurang baik di kelas maupun di luar kelas. Kecenderungan sikap yang kurang baik ini memiliki makna sama dengan sikap negatif. Contoh sikap sikap negatif yang relatif banyak dilakukan oleh siswa di SDN No. 075046 Lolofitu seperti: (1) tidak jujur/sering berbohong dan berpurapura; (2) kurang bertanggung jawab terhadap kewajiban dan tugas sebagai siswa; (3) kurang perduli dengan keadaan sekitar (kurang empati); dan (4) kurang santun; dan 5) kurang percaya diri.

Melalui studi pendahuluan yang dilakukan, pada kenyataanya guru SDN No. 075046 Lolofitu telah melakukan berbagai upaya untuk mereduksi sikap negatif siswa tersebut, tetapi pada kenyataannya berbagai usaha tersebut dianggap belum mampu mereduksi sikap negatif dan meningkatkan sikap positif siswa. Oleh karenanya peneliti merasa perlu melakukan sebuah tindakan yang belum pernah dilakukan sebelumnya di sekolah tersebut, yakni melalui teknik bimbingan konseling.

Dalam prakteknya ada beberapa layanan bimbingan konseling yang dapat dilakukan oleh guru di sekolah sebagai upaya pemecahan terhadap masalahmasalah yang terjadi, diantaranya adalah layanan konseling individual.

Layanan konseling individual merupakan layanan langsung tatap muka secara khusus oleh guru kepada siswa yang dimaksudkan untuk memungkinkan siswa memahami serta mengembangkan sikap positif dan kebiasaan yang baik serta tuntutan kemampuan yang berguna dalam kehidupan dan pengembangan dirinya.

Konseling individual yang digunakan dalam penelitian ini adalah konseling individual dengan teknik realitas. Glesser (dalam Wida \& Hadi, 2009) mengemukakan bahwa konseling realita adalah suatu sistem yang difokuskan pada tingkah laku sekarang, terapi ini berfungsi untuk membantu klien menghadapi kenyataan dan memenuhi kebutuhan - kebutuhan dasar tanpa merugikan dirinya sendiri maupun orang lain.

Dalam konseling realitas dijelaskan bahwa siswa harus menyadari potensi yang di miliki dirinya dan kesiapan 
dirinya menghadapi kondisi lingkungan yang kadang tidak sesuai dengan apa yang diharapkan siswa tersebut.

\section{KAJIAN PUSTAKA}

\section{Sikap}

Menurut Calhoun (1998) sikap merupakan kecenderungan pola tingkah untuk berbuat sesuatu dengan cara tertentu terhadap orang, benda atau gagasan. Sikap dapat diartikan sekelompok keyakinan dan perasaan yang melekat tentang objek tertentu dan kecenderungan untuk bertindak terhadap objek tersebut dengan cara tertentu.

Menurut Robert R.Gabe (dalam Siskandar, 2008) sikap merupakan kesiapan yang terorganisir yang mengarahkan atau mempengaruhi tanggapan individu terhadap objek. Sedangkan menurut Berkowitz (dalam Azwar, 1995) sikap adalah perasaan mendukung (favorable) atau tidak mendukung (unfavorable) terhadap objek tersebut.

Sikap menyangkut beberapa aspek, yaitu 1) jujur; 2) bertanggung jawab; 3) peduli; 4) santun, dan 5) percaya diri. Jujur dapat diartikan sebagai lurus hati, tidak berbohong/ tanpa adanya, tidak curang/ mengikuti aturan yg berlaku. Tanggung jawab artinya berkewajiban menanggung atau memikul. Peduli artinya mengindahkan, memperhatikan, dan menghiraukan. Santun artinya halus dan baik (budi bahasanya, tingkah lakunya), sabar dan tenang; sopan, penuh rasa belas kasihan dan suka menolong. Sedangkan percaya diri adalah yakin, tidak malu, dan tidak segan (KBI, 2003). Tanggung jawab siswa ada lima yaitu 1) Tanggung jawab belajar, 2) Tanggung jawab Mengerjakan Pekerjaan Rumah/ PR, 3) Tanggung jawab melaksanakan jadwal piket, 4) Tanggung jawab melakukan upacara bendera, dan 5) Tanggung jawab berbuat baik kepada guru dan teman sekolah.

Dalam pembelajaran sehari-hari, guru banyak dihadapkan dengan sikap siswa yang beraneka ragam. Dari beberapa sikap yang ditunjukkan oleh siswa, pada kenyataannya terdapat juga sikap sikap negatif. Oleh karenanya dibutuhkan sikap positif dari siswa. Sikap positif tersebut ditandai dengan: 1) jujur; 2) bertanggung jawab; 3) peduli; 4) santun; dan 5) percaya diri. Jujur dapat diartikan sebagai lurus hati, tidak berbohong/ tanpa adanya, tidak curang/ mengikuti aturan yg berlaku. Tanggung jawab artinya berkewajiban menanggung atau memikul. Peduli artinya mengindahkan, memperhatikan, dan menghiraukan. Santun artinya halus dan baik (budi bahasanya, tingkah lakunya), sabar dan tenang; sopan, penuh rasa belas kasihan dan suka menolong. Sedangkan percaya diri adalah yakin, tidak malu, dan 
tidak segan (KBI, 2003). Hal ini menjadi tantangan tersendiri bagi guru di kelas di tingkat sekolah dasar yang sekaligus berperan sebagai guru pembimbing disamping tugas utama sebagai guru kelas.

\section{Konseling Realita}

Konseling Realita merupakan suatu bentuk hubungan pertolongan yang praktis, relatif sederhana dan bentuk bantuan langsung kepada konseli, yang dapat dilakukan oleh guru atau konselor di sekolah dalam rangka mengembangkan dan membina kepribadian/kesehatan mental konseli secara sukses, dengan cara memberi tanggung jawab kepada konseli yang bersangkutan.

Terapi realita berprinsip seseorang dapat dengan penuh optimis menerima bantuan dari terapist untuk memenuhi kebutuhan-kebutuhan dasarnya dan mampu menghadapi kenyataan tanpa merugikan siapapun. Menurut Glasser (dalam Corey,G. 2009) konseling relita adalah membantu para klien dalam memenuhi kebutuhan- kebutuhan dasar psikologisnya, yang mencakup kebutuhan untuk mencintai dan dicintai serta kebutuhan untuk merasakan bahwa kita berguna baik bagi diri kita sendiri maupun bagi orang lain. Pandangan tentang manusia mencakup pernyataan bahwa suatu kekuatan pertumbuhan mendorong kita untuk berusaha mencapai suatu identitas keberhasilan. Glasser (dalam Corey, 2003) menguraikan teknik-teknik yang dipakai dalam konseling realita adalah sebagai berikut:

"Terlibat dalam permaianan peran konseli, menggunakan humor, mengkonfrontasi konseli, membantu konseli dalam merumuskan rencana-rencana yang spesifik bagi tindakan, bertindak sebagai model guru seperti memasang batas-batas dan menyusun situasi terapi, menggunakan "terapi kejutan verbal" atau sarkasme yang layak untuk mengkonfrontasi konseli dengan tingkah lakunya yang tidak realistis, melibatkan diri dengan konseli dalam upayanya mencari kehidupan yang lebih".

Berdasarkan kajian teori di atas, maka penulis merumuskan hipotesis penelitian sebagai berikut: upaya meningkatkan sikap positif siswa kelas V SD Negeri No. 075046 Lolofitu dapat dilakukan melalui penerapan konseling individual dengan teknik realitas.

\section{METODE PENELITIAN}

Penelitian ini termasuk penelitian tindakan Bimbingan Konseling. Lebih lanjut dijelaskan lagi bahwa, penelitian tindakan kelas dilakukan melalui proses yang dinamis dan komplementari yang terdiri dari empat momentum esensial, yakni: (1) Penyusunan rencana, (2) Tindakan, (3) Observasi, dan (4) Refleksi. 
Disain penelitian ini menggunakan penelitian tindakan Bimbingan dan Konseling dengan model siklus.

Pelaksanaan penelitian tindakan ini direncanakan dua siklus. Adapun prosedur pelaksanaan pada penelitian tindakan ini, didasarkan pada prosedur pelaksanaan yang dikemukakan oleh Kemmis dan Mc Taggart. Prosedur yang dilaksanakan terdiri dari empat tahap untuk satu siklus, yaitu: (1) Penyusunan rencana, (2) Tindakan, (3) Observasi, dan (4) Refleksi.

Tempat penelitian di SDN. 075046 Lolofitu Kecamatan Lolofitu Moi Kabupaten Nias Barat. Subjek penelitian adalah siswa kelas $\mathrm{V}$ di SD Negeri 075046 Lolofitu Kecamatan Lolofitu Moi Kabupaten Nias Barat Tahun Pembelajaran 2014/2015 yang berjumlah 21 orang siswa, dengan komposisi 13 siswa laki-laki dan 8 orang siswa perempuan.

Objek penelitian adalah peningkatan sikap siswa melalui layanan konseling individual dengan teknik realitas di kelas V SD Negeri No. 075046 Lolofitu kecamatan Lolofitu Moi Kabupaten Nias Barat.

\section{HASIL DAN PEMBAHASAN \\ PENELITIAN}

Hasil Penelitian Siklus I
Tahapan pertama yang dilakukan pada siklus ini adalah analisis data siswa yang telah diambil sebelumnya kepada guru kelas. Selanjutnya mengidentifikasi sikap positif siswa dan mengatur waktu pelaksanaan layanan konseling individual dengan teknik realitas.

Kedua adalah berdasarkan identifikasi sikap positif siswa, maka diadakan penyusunan instrumen lembar angket sikap positif siswa yang meliputi jujur, tanggung jawab, peduli, santun, dan percaya diri.

Adapun hal yang hendak dicapai dalam tindakan layanan ini adalah siswa sasaran layanan konseling individual dengan teknik realitas mampu menunjukkan perobahan sikap positif kearah yang lebih baik. Setiap layanan dilaksanakan selama dua jam pelajaran selama tujuh puluh menit dengan rincian: melaksanakan layanan bimbingan untuk 3 (tiga) orang siswa dan masing-masing siswa selama 20 menit dan waktu sela antara siswa pertama dan kedua, antara siswa kedua dan ketiga masing-masing 5 (lima) menit. Pada pertemuan hari terakhir disebarkan angket yang telah disiapkan untuk mengetahui dan mengukur skor dan persentase sikap positif siswa setelah diberi layanan konseling individual dengan teknik realitas.

\section{b. Pelaksanaan}


Berdasarkan pada hasil angket sikap positif siswa sebelumnya ( prasiklus) yang dibuktikan dengan rata-rata hitung hasil angket sikap positif siswa secara keseluruhan sebelum diberi layanan konseling individual dengan teknik realitas ( pra siklus ) adalah rata-rata sebesar 53,8 atau $44,8 \%$ dari skor maksimum 120 dengan perolehan nilai 1,3 yang artinya kurang baik.

Untuk masing-masing siswa diberi layanan konseling individual dengan teknik realitas dengan materi meliputi jujur, tanggung jawab, peduli, santun, dan percaya diri.

\section{c. Pengamatan}

Melaksanakan pengamatan sikap positif, tanggapan dan pendapat siswa selama berlangsungnya proses layanan bimbingan. Selanjutnya mengedarkan angket sikap positif siswa yang meliputi kejujuran, tanggung jawab, peduli, santun, dan percaya diri.

\section{Aspek Kejujuran}

Hasil rata-rata hitung skor sikap positif jujur siswa sebelum diberi layanan konseling individual dengan teknik realitas adalah total rata-rata sebesar 11,3 atau $40,4 \%$ dari skor maksimal 28 dengan penilaian angka 1,5 yang artinya kurang baik atau kurang jujur. Sedangkan setelah diberi layanan bimbingan, skor sikap positif jujur siswa naik menjadi 17,1 atau
$61 \%$ dari skor maksimal 28 dengan penilaian angka 2,4 yang artinya kejujuran siswa adalah cukup jujur.

Sebagai hasil dari dan kontribusi layanan konseling individual dengan teknik realitas yang telah dilakukan, kejujuran siswa naik sebesar 20, $6 \%$. sehingga dapat disimpulkan bahwa layanan konseling individual dengan teknik realitas dapat meningkatkan kejujuran siswa.

2. Apek Tanggung Jawab

Hasil rata-rata hitung skor tanggung jawab siswa sebelum diberi layanan konseling individual dengan teknik realitas adalah total rata-rata sebesar 13,6 atau 48,6\% dari skor maksimal 28 dengan penilaian angka 1,8 yang artinya cukup Sedangkan setelah diberi layanan bimbingan, skor tanggung jawab siswa naik menjadi 19 atau $67,8 \%$ dari skor maksimal 28 dengan penilaian angka 2,8 yang artinya tanggung jawab siswa adalah baik.

Sebagai hasil dari dan kontribusi layanan konseling individual dengan teknik realitas yang telah dilakukan, tanggung jawab siswa naik sebesar 19,2 $\%$. sehingga dapat disimpulkan bahwa layanan konseling individual dengan teknik realitas dapat meningkatkan tanggung jawab siswa.

3. Aspek Kepedulian Siswa 
Hasil rata-rata hitung skor sikap peduli siswa sebelum diberi layanan konseling individual dengan teknik realitas adalah total rata-rata sebesar 6,7 atau $41,8 \%$ dari skor maksimal 16 dengan penilaian angka 1,3 yang artinya kurang baik atau kurang peduli. Sedangkan setelah diberi layanan bimbingan, skor sikap peduli siswa naik menjadi 10,3 atau 64,3\% dari skor maksimal 16 dengan penilaian angka 2,3 yang artinya sikap peduli siswa adalah cukup.

Sebagai hasil dari dan kontribusi layanan konseling individual dengan teknik realitas yang telah dilakukan, sikap peduli siswa naik sebesar 22,5\% sehingga dapat disimpulkan bahwa layanan konseling individual dengan teknik realitas dapat meningkatkan sikap peduli siswa.

\section{Sikap Santun}

Hasil rata-rata hitung skor sikap santun siswa sebelum diberi layanan konseling individual dengan teknik realitas adalah total rata-rata sebesar 15,1 atau $47,1 \%$ dari skor maksimal 32 dengan penilaian angka 1,4 yang artinya kurang baik atau kurang santun. Sedangkan setelah diberi layanan bimbingan, skor sikap santun siswa naik menjadi 20,9 atau 65,3\% dari skor maksimal 32 dengan penilaian angka 2,3 yang artinya sikap santun siswa adalah cukup.
Sebagai hasil dari dan kontribusi layanan konseling individual dengan teknik realitas yang telah dilakukan, sikap santun siswa naik sebesar 18,2 \%. sehingga dapat disimpulkan bahwa layanan konseling individual dengan teknik realitas dapat meningkatkan sikap santun siswa.

\section{Sikap Percaya Diri}

Hasil rata-rata hitung skor sikap percaya diri siswa sebelum diberi layanan konseling individual dengan teknik realitas adalah total rata-rata skor sebesar 7,2 atau $45 \%$ dari skor maksimal 16 dengan penilaian angka 1,4 yang artinya kurang baik atau kurang percaya diri, sedangkan setelah diberi layanan bimbingan, skor sikap percaya diri siswa naik menjadi 10,4 atau $65 \%$ dari skor maksimal 16 dengan penilaian angka 2,4 yang artinya sikap percaya diri siswa adalah cukup.

Sebagai hasil dari dan kontribusi layanan konseling individual dengan teknik realitas yang telah dilakukan, sikap percaya diri siswa naik sebesar $20 \%$. sehingga dapat disimpulkan bahwa layanan konseling individual dengan teknik realitas dapat meningkatkan sikap percaya diri siswa.

\section{d. Refleksi}

Adapun keberhasilan dan kegagalan yang terjadi dalam pelaksanaan siklus 
pertama ini dapat diuraikan sebagai berikut: Rata-rata hitung skor sikap positif siswa keseluruhan setelah pelaksanaan layanan konseling individual dengan teknik realitas pada siklus I menunjukkan peningkatan yaitu dari 53,8 atau 44,8\% menjadi 77,6 atau $64,7 \%$ artinya naik $19,9 \%$. Rata-rata hitung skor sikap positif siswa keseluruhan pada siklus I masih belum mencapai batas ideal yang disyaratkan pada penelitian ini yaitu skor $\geq 85$ atau $\geq 71 \%$ dengan predikat baik. Dari 21 orang siswa kelas V SDN 075046 Lolofitu terdapat 3 orang siswa yaitu nomor kode $16 / \mathrm{V}, 20 / \mathrm{V}$, dan $21 / \mathrm{V}$ yang mencapai batas skor ideal yang disyaratkan dengan perolehan nilai 3 predikat baik. Pelaksanaan layanan konseling individual dengan teknik realitas siklus I bagi siswa kelas V SDN 075046 Lolofitu masih terkesan kaku, siswa merasa segan, kurang terbuka, materi layanan lebih menekankan pada perintah dan larangan.

Berdasarkan deskripsi hasil angket sikap positif siswa, temuan kelemahan pada saat pelaksanaan layanan bimbingan, maka layanan konseling individual dengan teknik realitas bagi siswa kelas V SDN 075046 Lolofitu dilanjutkan pada siklus kedua.

\section{Hasil Penelitian Siklus Kedua}

a. Perencanaan
Berdasarkan data yang diperoleh dari siklus pertama, maka peneliti melakukan rencana layanan bimbingan sebagai alternatif pemecahan masalah yang ditemukan pada siklus pertama. Adapun hal yang hendak dicapai dalam tindakan layanan ini adalah siswa sasaran layanan konseling individual dengan teknik realitas mampu menunjukkan sikap positif yang tinggi. Setiap layanan dilaksanakan selama dua jam pelajaran selama tujuh puluh menit dengan rincian: melaksanakan layanan bimbingan untuk 3 (tiga) orang siswa dan masing-masing siswa selama 20 menit dan waktu sela antara siswa pertama dan kedua, antara siswa kedua dan ketiga masing-masing 5 (lima) menit. Pada pertemuan hari terakhir disebarkarkan angket untuk mengetahui dan mengukur skor dan persentase sikap positif siswa setelah diberi layanan konseling individual dengan teknik realitas pada siklus kedua.

\section{b. Pelaksanaan}

Melaksanakan layanan konseling individual dengan teknik realitas dengan materi meliputi kejujuran, tanggung jawab, peduli, santun, dan percaya diri. Membangun komunikasi yang baik selama layanan bimbingan berlangsung. Sehingga siswa merasa nyaman dan tidak berada dalam tekanan. Berupaya mengedepankan kesetaraan, keterbukaan, 
dan saling percaya sehingga layanan bimbingan yang diberikan diterima dengan baik. Kata-kata yang disampaikan lebih sederhana, dapat dipahami siswa sasaran, dan bersifat ajakan dan arahan agar siswa menyadari akan sikap positifnya selama ini dan berusaha memperbaikinya.

\section{c. Pengamatan}

Mengamati sikap positif, tanggapan dan pendapat siswa selama berlangsungnya proses layanan bimbingan. Selanjutnya menganalis hasil angket sikap positif siswa yang telah diedarkan setelah pelaksanaan layanan konseling individual dengan teknik realitas yang meliputi kejujuran, tanggung jawab, peduli, santun, dan percaya diri. Adapun hasil yang diperoleh dari angket dapat dilihat sebagai berikut.

\section{Apek Sikap Jujur}

Hasil rata-rata hitung skor sikap jujur siswa pada siklus pertama sebagai data pembanding adalah total rata-rata sebesar 17,1 atau $61 \%$ dari skor maksimal 28 dengan penilaian angka 2,4 sedangkan setelah diberi layanan bimbingan pada siklus kedua skor sikap jujur siswa menjadi 21,5 atau $76,7 \%$ dari skor maksimal 28 dengan penilaian angka 3,2 dan predikat baik.

2. Apek Tanggung Jawab
Hasil rata-rata hitung skor sikap tanggung jawab siswa pada siklus pertama sebagai data pembanding adalah total rata-rata sebesar 19 atau $67,8 \%$ dari skor maksimal 28 dengan penilaian angka 2,8 sedangkan setelah diberi layanan bimbingan pada siklus kedua skor sikap tanggung jawab siswa menjadi 22,3 atau $79,8 \%$ dari skor maksimal 28 dengan penilaian angka 3,3 dan predikat baik.

3. Apek Sikap Peduli

Hasil rata-rata hitung skor sikap peduli siswa pada siklus pertama sebagai data pembanding adalah total rata-rata sebesar 10,3 atau $64,3 \%$ dari skor maksimal 16 dengan penilaian angka 2,3 sedangkan setelah diberi layanan bimbingan pada siklus kedua rata-rata skor sikap peduli siswa menjadi 13 atau $81,5 \%$ dari skor maksimal 16 dengan penilaian angka 3,0 dan predikat baik.

\section{Aspek Sikap Santun}

Hasil rata-rata hitung skor sikap santun siswa pada siklus pertama sebagai data pembanding adalah total rata-rata sebesar 20,9 atau $65,3 \%$ dari skor maksimal 32 dengan penilaian angka 2,3 sedangkan setelah diberi layanan konseling individu dengan teknik realitas pada siklus kedua rata-rata skor sikap positif santun siswa menjadi 25,2 atau $78,7 \%$ dari skor maksimal 32 dengan penilaian angka 3,0 dan predikat baik. 


\section{Aspek Percaya Diri}

Hasil rata-rata hitung skor sikap percaya diri siswa pada siklus pertama sebagai data pembanding adalah total rata-rata sebesar 10,4 atau $65 \%$ dari skor maksimal 16 dengan penilaian angka 2,4 sedangkan setelah diberi layanan bimbingan pada siklus kedua rata-rata skor sikap positif percaya diri siswa menjadi 13,4 atau $83,7 \%$ dari skor maksimal 16 dengan penilaian angka 3,2 dan predikat baik.

\section{d. Refleksi}

Setelah mengedarkan angket pada siklus pertama kepada siswa, kemudian dilakukan pengolahan data sebagai rujukan dalam pemberian layanan konseling individual dengan teknik realitas kepada siswa sasaran. Pada pertemuan hari terakhir pelaksanaan layanan konseling individual dengan teknik realitas diedarkan angket yang sama untuk melihat sikap positif siswa menyangkut sikap jujur, tanggung jawab, kepedulian, santun, dan percaya diri secara perorangan, yang selanjutnya dilakukan perbandingan. Setelah mengolah data perorangan maka dilakukan pengolahan tahap kedua untuk melihat data-data secara keseluruhan. Selanjutnya dari hasil olahan data keseluruhan ini dibuat deskripsi hasil temuan penelitian dalam bentuk tabel dan narasi yang dapat dilihat semuanya pada bab IV ini. Setelah itu, maka peneliti menarik kesimpulan dan mengajukan saran sebagai jawaban dan pemecahan masalah sesuai rumusan masalah yang telah diajukan sebelumnya.

Adapun simpulan yang bisa diambil dalam pelaksanaan siklus kedua ini dapat diuraikan sebagai berikut: Rata-rata hitung skor sikap positif siswa keseluruhan setelah pelaksanaan layanan konseling individual dengan teknik realitas pada siklus II menunjukkan peningkatan yaitu dari sebesar 77,6 atau 64,7 \% pada siklus sebelumnya menjadi 95,4 atau 79,5 \% artinya naik $14,8 \%$.

Rata-rata hitung skor sikap positif siswa keseluruhan pada siklus kedua sudah mencapai batas ideal yang disyaratkan pada penelitian ini yaitu skor $\geq 85$ atau $\geq 71 \%$ dengan predikat baik.

Siswa kelas V SDN 075046 Lolofitu yang berjumlah 21 orang telah mencapai batas skor ideal yang disyaratkan dengan perolehan nilai 3 dan predikat baik.

Pelaksanaan layanan konseling individual dengan teknik realitas siklus kedua bagi siswa kelas V SDN 075046 Lolofitu terkesan baik, siswa merasa senang, nyaman, terbuka, dan tidak dalam kondisi tertekan.

\section{Pembahasan}


1. Permasalahan Pokok Masalah Penelitian

Permasalahan pokok penelitian ini adalah a) Perbedaan sikap positif siswa sebelum dan sesudah diberi layanan konseling individual dengan teknik realitas yang meluputi sikap positif jujur, tangung jawab, kepedulian, kesantunan, dan percaya diri.; b) Layanan konseling individual dengan teknik realitas untuk meningkatkan sikap positif siswa.

\section{Jawaban Umum Atas Permasalahan}

\section{Pokok Masalah Penelitian}

Berdasarkan data yang diperoleh bahwa terdapat siswa yang terindikasi bersikap positif kurang baik, sedangkan setelah diberi layanan konseling individual dengan teknik realitas, sikap positif siswa menjadi meningkat. Hasil rata-rata hitung skor sikap positif siswa secara keseluruhan sebelum diberi layanan konseling individual dengan teknik realitas prasiklus adalah skor ratarata sebesar 53,8 atau 44,8\% menjadi 77,6 atau $64,7 \%$ pada siklus pertama dan pada siklus kedua memperoleh skor ratarata sebesar 95,4 atau 79,5\% dari skor ideal 120 dengan penilaian angka 3,0 yang artinya sikap positif siswa adalah baik, sehingga dapat disimpulkan bahwa layanan konseling individual dengan teknik realitas dapat meningkatkan sikap positif siswa menjadi meningkat.

\section{Analisis dan Interpretasi Temuan Penelitian}

Berdasarkan hasil olahan data yang telah dilakukan maka hasilnya adalah Layanan konseling individual dengan teknik realitas dapat meningkatkan sikap positif siswa yang meliputi jujur, tanggung jawab, kepedulian, kesantunan, dan percaya diri, hal ini menunjukan bahwa layanan konseling individual dengan teknik realitas yang dilakukan sangat berarti artinya layanan konseling individual dengan teknik realitas yang telah dieksperimenkan peneliti, sangat berperan meningkatkan sikap positif siswa dari kurang baik menjadi baik.

\section{Pengkontrasan Temuan Penelitian dengan Teori yang Ada}

Sikap positif adalah penilaian seseorang terhadap suatu obyek, situasi, konsep, orang lain maupun dirinya sendiri akibat hasil dari proses belajar maupun pengalaman di lapangan yang menyatakan rasa suka (respon positif) dan rasa tidak suka (respon negatif). Sikap positif merupakan salah satu tipe karakteristik afektif yang sangat menentukan keberhasilan seseorang dalam proses pembelajaran. Sikap positif menyangkut beberapa aspek, yaitu 1) Jujur, 2) Tanggung jawab, 3) Peduli, 4) Santun, dan 5) Percaya diri. 
Layanan konseling individual dengan teknik realitas adalah salah satu bidang dan jenis bimbingan dan konseling yang dapat memfasilitasi pengembangan sikap positif jujur, tanggung jawab, peduli, santun, dan sikap positif percaya diri menjadi lebih baik.

\section{PENUTUP}

\section{Simpulan}

Berdasarkan pokok permasalahan, kajian teori, dan hasil temuan penelitian, maka dipaparkan simpulan penelitian sebagai jawaban dan pemecahan masalah sesuai dengan rumusan masalah yang telah diajukan sebelumnya. Simpulan penelitian ini adalah: Tugas guru di sekolah dasar bukan hanya sekedar mengajar tetapi juga mendidik, melatih, dan membimbing siswa di kelas yang menjadi tanggung jawabnya.

Sebelum diberi layanan konseling individual dengan teknik realitas, sikap positif siswa yang meliputi sikap jujur, tanggung jawab, peduli, santun, dan percaya diri, total rata-rata skor sikap siswa adalah 53,8 atau $44,8 \%$ dari skor maksimum 120 artinya kurang baik. Sedangkan setelah diberi layanan konseling individual dengan teknik realitas pada siklus pertama dan siklus kedua, sikap positif siswa mengalami peningkatan, yaitu skor sikap positif siswa pada siklus pertama naik menjadi 77,6 atau $64,7 \%$ dari skor maksimum 120 dan skor sikap positif siswa pada siklus kedua naik menjadi $95,4 \%$ atau $79,5 \%$ dari hasil skor maksimum 120.

\section{Saran}

Dengan memperhatikan kegunaan dan berdasarkan simpulan penelitian di atas, maka diajukan saran-saran sebagai berikut :Guru-guru kelas atau wali kelas di sekolah dasar, agar memberikan layanan konseling individual dengan teknik realitas untuk meningkatkan sikap positif siswa. Siswa-siswa sekolah dasar hendaknya mengikuti dengan seksama layanan konseling individual dengan teknik realitas yang diselenggarakan guru untuk meningkatkan sikap positif siswa. Disarankan kepada Pemerintah (Dinas Pendidikan Kabupaten Nias Barat) untuk merencakan dan menyelenggarakan pelatihan peningkatan profesionalisme guru guru Sekolah Dasar dalam melaksanakan konseling individual dengan teknik realitas. Untuk penelitipeneliti selanjutnya, disarankan agar mengadakan kajian yang lebih mendalam tentang sikap positif siswa sekolah dasar dan konseling individual dengan teknik realitas, sehingga kajian-kajian yang sama degan penelitian ini dapat menjadi lebih sempurna.

\section{DAFTAR PUSTAKA}


Arikunto, dkk. 2008. Dasar-Dasar Evaluasi Pendidikan (Edisi Revisi). Bandung: Bumi Aksara

Corey, G. 2009. Teori Dan Praktek Konseling \& Psikoterapi. Bandung: PT Refika Utama

Depdiknas. 2008. Bimbingan dan Penyuluhan di Sekolah. Jakarta: Depdiknas

Hera L.M, Agus T, \& Puji L.P. 2007. Pendidikan Anak di SD. Jakarta: Universitas Terbuka.

Kapur Tulis. 2012. Sikap Siswa Dalam Belajar.

https://acenale.wordpress.com/201 2/03/14/sikap-siswa-dalambelajar/, pada taggal 13 Februari 2015.

KBBI. 2003. Kamus Besar Indonesia Elektronik/ Indonesian Dictionary.

Kemendikbud. 2014. Permendikbud Nomor 104 Tahun 2014. Jakarta: Kemendikbud.

Kunandar. 2008. Langkah Mudah Penelitian Tindakan Kelas. Jakarta: Rajawali Pers.
Panji. 2012. Tanggung Jawab Seorang Pelajar.

http://panjiploembond.blogspot.co $\mathrm{m} / 2012 / 04 / 5$-tanggung-jawabseorang-pelajar/ pada tanggal 23 Maret 2015.

Pusat Bahasa Depdiknas. 2001. Kamus Besar Bahasa Indonesia. Jakarta : Balai Pustaka.

Rianta, Andrey. 2012. Pendekatan Konseling Realita. (http:/bimbingannews.blogspot.co $\mathrm{m} / 2012 / 12 /$ pendekatan-konselingrealistis.html), diakses 22 Maret 2015.

Rizca, Fitria. 2014. Sikap Belajar Peserta Didik.

https://rizcafitria.wordpress.com/2 011/04/30/sikap-belajar-pesertadidik/, pada tanggal 03 Maret 2015.

Tarmizi. 2009. Komponen Pembentukan Sikap Belajar Siswa. https://tarmizi.wordpress.com/200 9/03/08/komponen-pembentukansikap-belajar-siswa/, pada tanggal 13 Februari 2015. 